\title{
Harlequin Color Change: Neonatal Case Series and Brief Literature Review
}

\author{
Enrico Valerio, $\mathrm{MD}^{1} \quad$ Alessia Barlotta, $\mathrm{MD}^{1} \quad$ Eleonora Lorenzon, $\mathrm{MD}^{1} \quad$ Livio Antonazzo, $\mathrm{MD}^{1}$ \\ Mario Cutrone, $\mathrm{MD}^{2}$ \\ ${ }^{1}$ Department of Woman and Child Health, Medical School, University \\ of Padua, Padova, Italy \\ 2 Department of Pediatrics, Ospedale Dell'Angelo, Mestre, Venice, Italy \\ Address for correspondence Enrico Valerio, MD, Department of \\ Woman and Child Health, Medical School, University of Padua, Via \\ Giustiniani, 3, 35128 Padova, Italy \\ (e-mail: enrico.valerio.md@gmail.com; enrico.va@inwind.it).
}

Am J Perinatol Rep 2015;5:e73-e76.

\begin{abstract}
Keywords

- harlequin color change

- preterm

- neonate

- infant

- dermatology

First clinical report of Harlequin color change (HCC) phenomenon came in 1952 from Neligan and Strang. Since then, HCC has been described in a fairly broad number of clinical reports involving neonates, infants, children, and adult patients. We here present a small case series of HCC occurring in neonates, pointing out three of the different possible presentations (hemifacial, patchy scattered across the whole body, and hemiscrotal) of this phenomenon. A brief discussion and literature review encompassing epidemiology, clinical features, physiopathology, associated conditions, and differential diagnoses of HCC is then presented. In most cases, HCC represents a benign, idiopathic, and rapidly autoresolutive phenomenon, with no need for treatment. Some drugs (especially anesthetics and prostaglandin E) are thought to enhance HCC expression through their influence on the capillary tone in the peripheral vascular bed; this effect is anyway promptly reversible with drug withdrawal. Only in rare circumstances, HCC may act as a clue for serious central nervous system disorders (e.g., meningitis; hypothalamic, brain stem, or sympathetic nervous system lesions); anyway, in these rare occurrences HCC always represents an epiphenomenon of the disease, never acting as the sole sign of the underlying disorder.
\end{abstract}

First clinical report of a curious autonomic vascular phenomenon occurring in neonatal period, characterized by a fleeting split appearance of skin into two well-demarcated color areas, came in 1952 from Neligan and Strang, ${ }^{1}$ who named it "Harlequin colour change" (HCC) after the famous Venetian carnival mask dressed in patches of different colors.

Since then, HCC has been described in a fairly broad number of reports involving neonates, ${ }^{2-15}$ infants, ${ }^{16-20}$ children, ${ }^{21-24}$ and adult patients, ${ }^{25-58}$ either as an isolated finding or as secondary to a specific condition (e.g., exercise, iatrogenic damage, and associated diseases).

\section{Case 1}

A late preterm male neonate was born vaginally; he was put in antibiotic prophylaxis with IV ampicillin and netilmicin because of the maternal history of premature rupture of membranes. At 4 days of life, he developed a transient erythematous rash on the right side of the face, on which he was decumbent ( - Fig. 1); the rest of the body was not interested. The rash rapidly vanished within 2 minutes from its start.

\section{Case 2}

A Moroccan male preterm newborn was delivered by caesarean section at $31+3$ weeks of gestational age because of altered cardiotocographic pattern; he did very well in delivery room, not needing any resuscitation. About 10 minutes after the delivery, during acute crying, he suddenly developed a patchy skin pattern, with regional clear-cut edge cutaneous discoloration of face, right forearm, right leg, and left knee (-Fig. 2); skin returned evenly pink in a few minutes. received

October 22, 2014 accepted after revision

December 30, 2014

published online

March 2, 2015
DOI http://dx.doi.org/

10.1055/s-0035-1545671. ISSN 2157-6998.
Copyright (c) 2015 by Thieme Medical Publishers, Inc., 333 Seventh Avenue, New York, NY 10001, USA. Tel: +1(212) 584-4662.
License terms

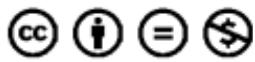




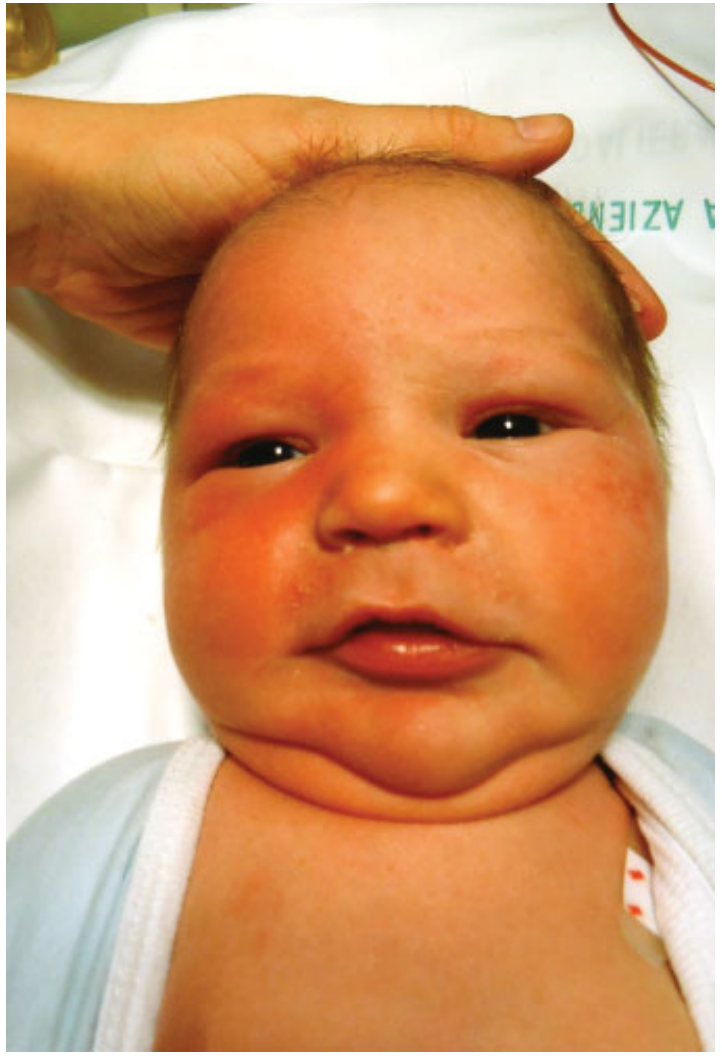

Fig. 1 Facial harlequin color change in a late preterm White newborn administered IV antibiotic therapy for a vaginal delivery with history of premature rupture of membranes; the baby was on his right side when the rash began. Overall phenomenon lasted 2 minutes and then rapidly vanished.

\section{Case 3}

A term, healthy neonate developed an altered color of the right hemiscrotum soon after a bath ( - Fig. 3); no other body region was interested in the phenomenon, which quickly regressed in about 1 minute leaving no trace.

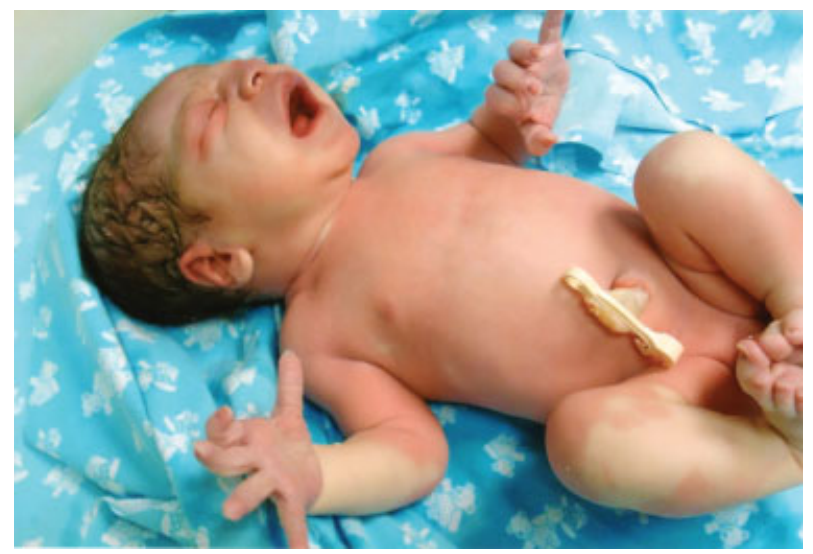

Fig. 2 Harlequin phenomenon in a Moroccan preterm newborn (31 weeks' gestational age). Regional, clear-cut edge skin discoloration started 10 minutes after delivery during intense crying, involving face and right hemibody of the neonate, and vanished minutes after.

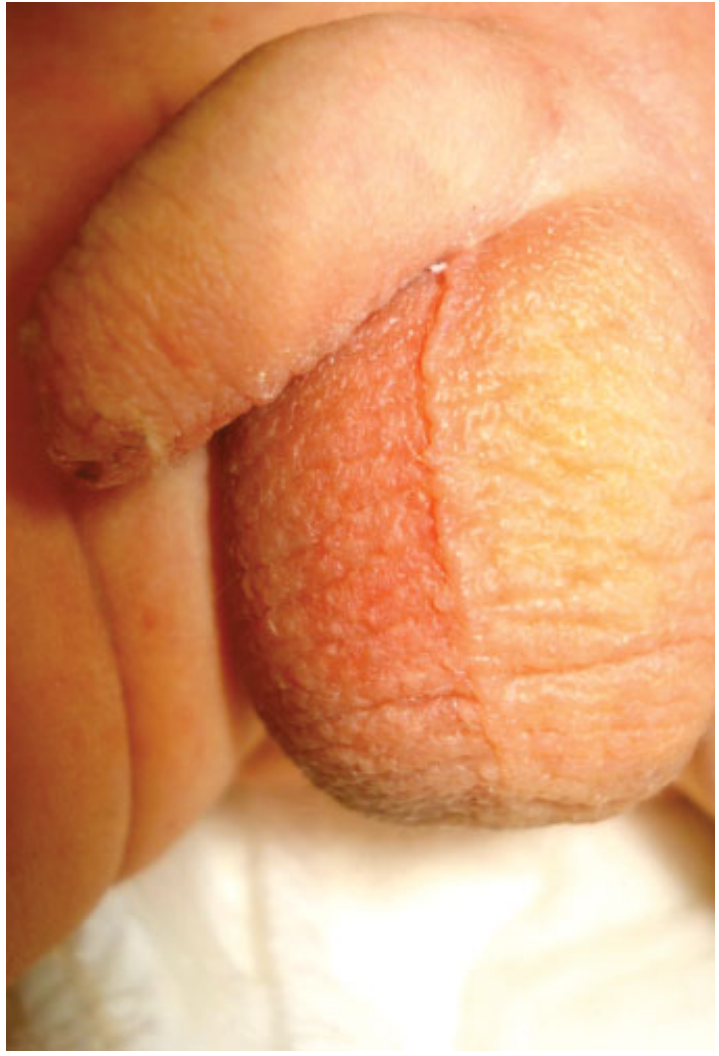

Fig. 3 Harlequin color change of the right hemiscrotum in a term Caucasian neonate after bath. The baby was otherwise asymptomatic. No other skin district was interested. Phenomenon quickly regressed in 1 minute, leaving scrotum evenly pink.

\section{Discussion}

\section{Epidemiology}

HCC appears transiently in as up to $10 \%$ of healthy newborns, ${ }^{9}$ more commonly on days 2 to 5 of life, ${ }^{9,17}$ although it has been reported even later in a neonatal age. ${ }^{14}$

First reports published about HCC suggest a raised prevalence in "small for gestational age, especially preterm neonates," 1 observation confirmed by some recent articles too ${ }^{5,13,20}$; on the contrary, several new observations register HCC as a common finding also in full-term neonates. ${ }^{6,8,9,14}$

\section{Clinical Features}

In most cases, HCC expression consists in a sudden change in skin color, more often with a distinct limiting edge along body midline (see - Figs. 1 and 3), dividing neonate body skin into a pale half and a plethoric (usually the decumbent) half $^{15}$; occasionally, HCC can present itself in a patchy fashion, again with sharp edge borders (see - Fig. 2), ${ }^{14}$ sometimes sparing arms, legs, trunk, face, and/or genitalia. ${ }^{2,3}$ HCC usually is a brief and quickly reversing phenomenon; skin returns uniformly colored in a few minutes. ${ }^{8,9}$ 
Of note, most commonly HCC happens in the absence of accompanying signs or symptoms; particularly, no concurrent autonomic dysregulation symptoms (such as respiratory rate, heart beat frequency, pupil diameter, or tone alterations) are evident during an HCC episode. ${ }^{6,20}$

\section{Physiopathology and Associated Conditions}

Exact mechanisms responsible for HCC are still unknown, but quite robust evidence accounts for a sympathetic autonomic dysfunction in the control of peripheral capillary bed tonus, probably because of the hypothalamic functional immaturity in the newborn ${ }^{1-3,17-19}$; therefore, erythematous and pale skin areas result from unregulated regional capillary vasodilatation and vasoconstriction, respectively.

Associated conditions and medications may possibly accompany and/or enhance HCC phenomenon, either by influencing the peripheral vascular tone and reactivity (prostaglandin $\mathrm{E}^{8}$ some anesthetics ${ }^{17,43}$ ) or by being further expressions of central autonomic disturbance (meningitis, ${ }^{5}$ seizures, ${ }^{18}$ and-in late childhood and adulthood-headache, $^{32,33}$ parasomnia, ${ }^{51}$ and sweating disorders ${ }^{54}$ ).

HCC can also be associated with congenital, acquired or iatrogenic lesions of hypothalamus, brain stem, cervical sympathetic nervous system, or of the second and third spinal cord thoracic segments. ${ }^{15}$ However, most cases of the HCC are classified as idiopathic. ${ }^{47,52}$

\section{Differential Diagnoses}

HCC characteristics make it unlikely to be confused with other systemic rashes. Anamnesis plays a key role in distinguishing HCC from other types of rash (history of fever and flu-like symptoms in parvovirus B19 infection ${ }^{59}$; previous drugs intake in Steven Johnsons syndrome ${ }^{60}$ ), as does peculiar presentation of HCC (fleeting, well-demarcated rash, usually involving half of the body) in contrast to that of different rashes (generalized and poorly delimited eruption in parvovirus B19 infection ${ }^{59}$; vesicular or papular eruption in varicella $^{61}$ and measles, ${ }^{62}$ respectively; pruritic, pomfoid elements in urticaria ${ }^{63}$; painful red or purplish rash with skin dead and shedding in Steven Johnsons syndrome ${ }^{60}$ ).

Finally, HCC in the neonate most often is not accompanied by any other significant symptom.

\section{Conclusions and Final Remarks}

In most cases, HCC represents a benign, idiopathic, and rapidly autoresolutive phenomenon, with no need for treatment. Some drugs (especially anesthetics and prostaglandin E) are thought to enhance HCC expression through their influence on the capillary tone in the peripheral vascular bed; this effect is anyway promptly reversible with drug withdrawal.

Only in rare circumstances, HCC may act as a clue for serious central nervous system disorders (e.g., meningitis; hypothalamic, brain stem, or sympathetic nervous system lesions); anyway, in these rare occurrences HCC always represents an epiphenomenon of the disease, never acting as the sole sign of the underlying disorder.
Conflicts of Interest

None.

\section{References}

1 Neligan GA, Strang LB. A "harlequin" colour change in the newborn. Lancet 1952;2(6743):1005-1007

2 Lucky AW. Transient benign cutaneous lesions in the newborn. In: Eichenfield LF, Frieden IJ, Esterly NB, eds. Neonatal Dermatology, 2nd ed. Philadelphia, PA: Saunders Elsevier; 2008:85-97

3 Morelli JG. Diseases of the neonate. In: Kliegman RM, Behrman RE, Jenson HB, Stanton BF, eds. Nelson Textbook of Pediatrics, 18th ed. Philadelphia, PA: Saunders Elsevier; 2007:2661-2664

4 Velayuthan S, Sankararaman S. Visual diagnosis: newborn who has unilateral color change. Diagnosis: Harlequin color change. Pediatr Rev 2013;34(7):e25-e26

5 Lee RS, Wan HS, Chan RL. Harlequin colour change in a newborn with meningitis. Hong Kong Med J 2012;18(6):539.e3-539.e4

6 Tang J, Bergman J, Lam JM. Harlequin colour change: unilateral erythema in a newborn. CMAJ 2010;182(17):E801

7 Hartdorff CM, Valks SD. Diagnostic image (328). A neonate with a unilateral red discoloration of the face [in Dutch]. Ned Tijdschr Geneeskd 2007;151(24):1344

8 Rao J, Campbell ME, Krol A. The harlequin color change and association with prostaglandin E1. Pediatr Dermatol 2004;21(5): 573-576

9 Selimoğlu MA, Dilmen U, Karakelleoğlu C, Bitlisli H, Tunnessen WW Jr. Picture of the month. Harlequin color change. Arch Pediatr Adolesc Med 1995;149(10):1171-1172

10 Baba K, Iino Y. The harlequin color change of the newborn infant. Paediatr Univ Tokyo 1962;7:30-31

11 Mortensen O, Stougard-Andresen P. Harlequin colour change in the newborn. Acta Obstet Gynecol Scand 1959;38:352-358

12 Birdsong M, Edmunds JE. Harlequin color change of the newborn; report of a case. Obstet Gynecol 1956;7(5):518-521

13 Dang D, Zhou W, Liu Y, Wu H. Harlequin color change in two preterm newborns. J Dermatol 2014;41(1):102-103

14 Rao J, Krol A. Images in clinical medicine. The harlequin color change. N Engl J Med 2003;349(10):968

15 Januário G, Salgado M. The Harlequin phenomenon. J Eur Acad Dermatol Venereol 2011;25(12):1381-1384

16 Pearson HA, Cone TE Jr. Harlequin color change in a young infant with tricuspid atresia. J Pediatr 1957;50(5):609-612

17 Wagner DL, Sewell AD. Harlequin color change in an infant during anesthesia. Anesthesiology 1985;62(5):695

18 Zelnik N, Nir A, Amit S, lancu TC. Autonomic seizures in an infant: unusual cutaneous and cardiac manifestations. Dev Med Child Neurol 1990;32(1):74-78

19 Morrison DA, Bibby K, Woodruff G. The "harlequin" sign and congenital Horner's syndrome. J Neurol Neurosurg Psychiatry 1997;62(6):626-628

20 Padda GS, Cruz OA, Silen ML, Krock JL. Skin conductance responses in paediatric Harlequin syndrome. Paediatr Anaesth 1999;9(2): 159-162

21 Breunig JdeA, Hartmann M, Freire CF, de Almeida HL Jr. Harlequin syndrome in childhood-case report. An Bras Dermatol 2012; 87(6):907-909

22 Turco GR, Farber NE. Postoperative autonomic deficit: a case of harlequin syndrome. Anesthesiology 1996;85(5):1197-1199

23 Kerbl R, Schwinger W, Lackner H, Dornbusch HJ, Urban CE. Peripheral harlequin-like thermal imbalance after Wilms' tumor. J Pediatr 2000;137(6):887

24 Sabir H, Babor F, Kieseier BC, Mayatepek E, Assmann B. Unilateral facial flushing and sweating after physical exercise: Harlequin syndrome. Klin Padiatr 2011;223(2):90-91 
25 Tascilar N, Tekin NS, Erdem Z, Alpay A, Emre U. Unnoticed dysautonomic syndrome of the face: Harlequin syndrome. Auton Neurosci 2007;137(1-2):1-9

26 Sribnick EA, Boulis NM. Treatment of Harlequin syndrome by costotransversectomy and sympathectomy: case report. Neurosurgery 2011;69(1):E257-E259

27 Bohlega S, Stigsby B, Al Mohaileb F. Teaching neuroimages: harlequin syndrome caused by lesion of sympathetic regulatory neurons. Neurology 2010;74(24):e106

28 Oller K, Cao K, Parkerson J, Lezama J. Stop, you're making me blush. Am J Med 2011;124(4):301-302

29 Kalapesi FB, Krishnan AV, Kiernan MC. Segmental facial anhidrosis and tonic pupils with preserved deep tendon reflexes: a novel autonomic neuropathy. J Neuroophthalmol 2005;25(1):5-8

30 Mashour GA, Levine W, Ortiz VE. Intraoperative Harlequin syndrome. Anesth Analg 2006;102(2):655

31 Burlacu CL, Buggy DJ. Intraoperative Harlequin syndrome. Anesth Analg 2007;104(3):748-749

32 Viana M, Mathias CJ, Goadsby PJ. Headache in three new cases of Harlequin syndrome with accompanying pharmacological comparison with migraine. J Neurol Neurosurg Psychiatry 2012;83(6): 663-665

33 Drummond P, Lance JW. Harlequin syndrome: does a cranial autonomic neuropathy influence headache? J Neurol Neurosurg Psychiatry 2012;83(6):577

34 Duddy ME, Baker MR. Images in clinical medicine. Harlequin's darker side. N Engl J Med 2007;357(20):e22

35 Moon SY, Shin DI, Park SH, Kim JS. Harlequin syndrome with crossed sympathetic deficit of the face and arm. J Korean Med Sci 2005;20(2):329-330

36 Jiménez-Caballero PE. Harlequin syndrome secondary to thoracic chondrosarcoma[in Spanish]. Rev Neurol 2008;46(4):252-253

37 Díaz-Soto G, Vaquerizo MJ. García-Álvarez C, Villar-Bonet A. Harlequin syndrome post-transsphenoidal pituitary macroadenoma surgery. Hormones (Athens) 2012;11:207-209

38 Fallon KE, May JJ. Harlequin syndrome in two athletes. Br J Sports Med 2005;39(1):e1

39 Toll A, Gálvez-Ruiz A. Harlequin syndrome after jogging. Med J Aust 2011;195(5):288

40 Sarikaya H, Georgiadis D, Baumgartner RW. Harlequin syndrome in spontaneous dissection of the cervical carotid artery. Neurology 2008;71(18):1459

41 Noda S. Harlequin syndrome due to superior mediastinal neurinoma. J Neurol Neurosurg Psychiatry 1991;54(8):744

42 Pradeep PV, Benede AK, Harshita SS, Jayashree B. Harlequin syndrome in a case of toxic goitre: a rare association. Case Rep Med 2011;2011:293076

43 Tyrrell JR, Trumpelmann P, Chamberlain MH. Harlequin syndrome after extrapleural bupivacaine infusion. Br J Anaesth 2012;109(2): 295-296
44 Umeki S, Tamai H, Yagi S, Soejima R, Higashi Y. Harlequin syndrome (unilateral flushing and sweating attack) due to a spinal invasion of the left apical lung cancer [in Japanese]. Rinsho Shinkeigaku 1990; 30(1):94-99

45 Corbett M, Abernethy DA. Harlequin syndrome. J Neurol Neurosurg Psychiatry 1999;66(4):544

46 Willaert WI, Scheltinga MR, Steenhuisen SF, Hiel JA. Harlequin syndrome: two new cases and a management proposal. Acta Neurol Belg 2009;109(3):214-220

47 Lance JW, Drummond PD, Gandevia SC, Morris JG. Harlequin syndrome: the sudden onset of unilateral flushing and sweating. J Neurol Neurosurg Psychiatry 1988;51(5):635-642

48 Cheshire WP Jr, Low PA. Harlequin syndrome: still only half understood. J Neuroophthalmol 2008;28(3):169-170

49 Wasner G, Maag R, Ludwig J, et al. Harlequin syndrome-one face of many etiologies. Nat Clin Pract Neurol 2005;1(1):54-59

50 ten Holter JB, Visser A. Harlequin syndrome [in Dutch]. Ned Tijdschr Geneeskd 1997;141(51):2495-2499

51 Lombardi C, Vetrugno R, Provini F, et al. Harlequin syndrome: an association with overlap parasomnia. J Neurol Neurosurg Psychiatry 2004;75(2):341-342

52 Biondi A, Persiani R, Zoccali M, Rausei S, Cananzi F, D'Ugo D. Harlequin syndrome. Ann Thorac Surg 2009;88(1):304

53 Malaviya AP, Ostor AJ. Clinical image: The Harlequin sign-benign blush or the bearer of bad news? Arthritis Rheum 2012;64(7): 2403

54 Freeman R, Waldorf HA, Dover JS. Autonomic neurodermatology (Part II): Disorders of sweating and flushing. Semin Neurol 1992; 12(4):394-407

55 Paul I, Kenny S, McManus K. Apical schwannoma presenting as harlequin syndrome. Ann Thorac Surg 2013;96(6):2248

56 Lin SH, Chen CI, Liu CC, Du MH, Lam C. An old lady with anterior chest pain and unilateral facial flushing. Am J Emerg Med 2012; 30(1):248.e1-248.e4

57 Hojo N, Saito T, Abe K, Iijima Y. A case of idiopathic harlequin syndrome. Intern Med 2011;50(21):2707

58 Fernández De Orueta L, Esteban Fernández J, Giménez Sánchez De La Blanca A, García Aguado C. Harlequin syndrome [in Spanish]. Med Clin (Barc) 2011;137(8):382

59 Kerr JR. Parvovirus B19 infection. Eur J Clin Microbiol Infect Dis 1996;15(1):10-29

60 Kirchhof MG, Miliszewski MA, Sikora S, Papp A, Dutz JP. Retrospective review of Stevens-Johnson syndrome/toxic epidermal necrolysis treatment comparing intravenous immunoglobulin with cyclosporine. J Am Acad Dermatol 2014;71(5):941-947

61 Berkoff MC, Brown WD. Varicella after the perinatal period. Pediatr Rev 2013;34(11):537-538

62 Naim HY. Measles virus. Hum Vaccin Immunother 2014;5:e34298

63 Spickett G. Urticaria and angioedema. J R Coll Physicians Edinb 2014;44(1):50-54 